JURNAL HUMANIORA

TEKNOLOGI

Vol. 1 No.1 ; Oktober 2015

\title{
PENGENDALIAN INTERN \\ DALAM BERWIRAUSAHA PADA TOKO NABIL
}

\author{
RADNA NURMALINA
}

Dosen Jurusan Teknik Informatika, Politeknik Negeri Tanah Laut

Jl. A. Yani Km. 6 Ds. Panggung Kec. Pelaihari Kab. Tanah Laut, Kalimantan Selatan

e-mail: radnanurmalina@yahoo.co.id

\begin{abstract}
Abstrak
Pengendalian merupakan proses untuk memeriksa kembali, menilai dan selalu memonitor laporan-laporan apakah pelaksanaanya tidak menyimpang dari tujuan yang telah ditetapkan, oleh karena itu adanya suatu langkah perbandingan antara hasil yang ditetapkan dalam perencanaan untuk mengetahui dan menilai prestasi masa lalu serta meletakan tanggung jawab jika ada penyimpangan yang terjadi, denagan demikian pelaksanaan akan lebih efektif dan efisien. Pengendalian adalah wewenang untuk mengatur dan menentukan kebijakan keuangan dan operasi dari suatu kegiatan usaha dengan tujuan untuk mendapat manfaat dari kegiatan tersebut.

Pengendalian intern sangat diperlukan dalam berwirausaha sehingga pemilik usaha bisa mengendalikan biaya operasional untuk meningkatkan laba usahanya. Wirausahawan yang mengelola unit usaha perlu membuat anggaran yang realistis, khususnya yang berkaitan dengan pengendalian intern dan memperhatikan otorisasi pengeluaran biaya yang konsisten atau pengeluaran biaya yang sesuai dengan perencanaan.
\end{abstract}

Kata kunci : pengendalian intern, biaya operasional, anggaran

\section{PENDAHULUAN}

Perusahaan besar, menengah atau kecil memerlukan biaya untuk mendukung kegiatannya, sehingga tiap unit usaha tidak akan sama besar kecilnya dalam penggunaan biaya, yang terpenting dalam hal ini bukan besar biaya yang diperhatikan tetapi bagaimana pihak manajemen mampu menggunakan biaya tersebut secara efektif dan efisien oleh sebab itu titik pelaksanaan penegendalian selain sebagai langkah untuk mengadakan penilaian atau memonitor pelaksanaan dan laporan keuangan, juga sebagai langkah penetapan tanggung jawab serta pengusaha ketetapan waktu dan keseimbangan antara realisasi biaya dengan jumlah anggaran yang ditetapkan, apabila realisasi biaya jauh lebih besar dari anggaran yang ditetapkan maka sebenarnya titik pelaksanaan pengendalian itu dapat dilaksanakan, oleh 
sebab itu perlu adanya standar yang menjadi alat untuk melaksanakan penilaian keberhasilan atau ketidakberhasilan pelaksanaan rencana anggaran tersebut.

Pengendalian merupakan proses untuk memeriksa kembali, menilai dan selalu memonitor laporan-laporan apakah pelaksanaanya tidak menyimpang dari tujuan yang telah ditetapkan, oleh karena itu adanya suatu langkah perbandingan antara hasil yang ditetapkan dalam perencanaan untuk mengetahui dan menilai prestasi masa lalu serta meletakan tanggung jawab jika ada penyimpangan yang terjadi, denagan demikian pelaksanaan akan lebih efektif dan efisien. Pengendalian adalah wewenang untuk mengatur dan menentukan kebijakan keuangan dan operasi dari suatu kegiatan usaha dengan tujuan untuk mendapat manfaat dari kegiatan tersebut.

Setiap unit usaha mempunyai tujuan untuk mendapatkan laba maksimal dan wirausahawan berusaha untuk mencapainya. Pengendalian biaya sangat penting dan harus dilaksanakan secara tepat sesuai dengan keadaan usaha terutama berkaitan dengan biaya operasional. Biaya operasional bersifat variabel sesuai dengan keadaan volume kegiatan usaha, tetapi biaya operasional masih bisa dilakukan pengendalian atau diupayakan penggunaanya secara efektif dan efisien, sehingga dapat diharapkan adanya kenaikan perolehan laba usaha.

TABEL 1: Toko Nabil Pelaihari

Perbandingan Penjualan Bersih, Biaya Operasinal dan Laba Usaha Tahun 2011,2012,2013

\begin{tabular}{|l|l|l|l|l|l|l|l|}
\hline No & Tahun & Penjualan Bersih & $\%$ & $\begin{array}{c}\text { Biaya } \\
\text { Operasional }\end{array}$ & $\%$ & Laba Usaha & $\%$ \\
\hline 1 & 2011 & Rp. 97.600 .000 & 100 & Rp. 17.568.000 & 18 & Rp. 35.136.000 & 36 \\
\hline 2 & 2012 & Rp. 102.400.000 & 100 & Rp. 19.456.000 & 19 & Rp. 33.792.000 & 33 \\
\hline 3 & 2013 & Rp. 106.000.000 & 100 & Rp. 22.260.000 & 21 & Rp. 31.800.000 & 30 \\
\hline
\end{tabular}

Sumber: Toko Nabil Pelaihari

Berdasarkan pada tabel 1 terjadi kecenderungan peningkatan biaya operasional tersebut akan memperkecil perolehan laba usaha pada Toko Nabila dengan peningkatan biaya operasional setiap tahunnya mengalami kenaikan dari tahun 2011 sebesar 18\%, tahun 
2012 sebesar $19 \%$ dan tahun 2013 sebesar $21 \%$, sedangkan penurunan laba setiap tahunnya sebesar 3\% dari tahun 2011 sebesar 36\%, tahun 2012 sebesar 33\%, tahun sebesar 30\%.

\section{LANDASAN TEORI}

\section{Pengendalian Intern}

Pengendalian intern (internal control) mempunyai pengertaian sempit dan luas. Dalam pengertian sempit (Zaki Baridwan, 2009) memberikan rumusan pengendalian intern merupakan pengecekan, penjumlahan, baik penjumlahan mendatar maupun menurun, namun pengertian luas pengedalian intern tidak hanya meliputi pekerjaan, pengecekan, tetapi meliputi alat-alat yang digunakan manajemen untuk mengadakan pengawasan.

Menurut (Mulyadi, 2005) pengendalian intern dapat dibagi menjadi 2 macam, yaitu pengendalian intern akuntansi dan pengendalian intern administratif. Pengedalian intern akuntasi bertujuan menjaga kekayaan organisasi dan mengecek ketelitian juga keandalan akuntansi, sedangkan pengenalian intern administratif bertujuan mendorong efisiensi dan mendorong dipatuhinya kebijakan manajemen.

\section{Biaya Operasional}

Menurut (Mulyadi: 2005) biaya operasi yang dikeluarkan untuk biaya operasional usaha suatu perusaahan. Biaya operasi ini dikelompokkan menjadi:

1. Biaya tetap, yaitu biaya yang jumlahnya tetap dalam kisaran volume kegiatan tertentu.

2. Biaya semi tetap, yaitu biaya yang tetap untuk tingkat volume kegiatan tertentu dan perubahan dengan jumlah yang konstan pada volume produksi tertentu.

3. Biaya variabel, yaitu biaya yang jumlah totalnya berubah dengan perubahan volume kegiatan.

4. Biaya semi variabel, yaitu biaya yang berubah tidak sebanding dengan perubahan volume kegiatan.

\section{Anggaran Untuk Perencanaan dan Pengendalian (Budget For Planning and Control)}

Bagian penting dari akuntasi manajemen adalah membandingkan kinerja aktual dengan standar untuk memastikan bahwa tujuan perusahaan telah terjadi. Sistem penganggaran adalah suatu bagian esensial perusahaan dari perencanaan dan pengendalian. Anggaran merupakan rencana-rencana rinci yang dibuat oleh manajemen. Untuk membuat rencana yang rinci tersebut manajemen harus membuat standar kinerja yang tepat dalam 
setiap jangkauan operasi perusahaan. Sebagai jumlah unit-unit produk yang diharapkan untuk dijual harus diperkirakan terlebih dahulu, sebagai tambahan lain seperti penerimaan kas dan pemakaian kas harus direncanakan atau dianggarkan.

Jenis perencanaan formal ini dipergunakan sebagai proses pengendalian. Setelah perusahaan memulai operasi pada suatu periode, jumlah yang dianggarkan dapat dibandingkan dengan kinerja aktual dan tindakan perbaikan (corrective action) dapat diambil apabila diperlukan (Tunggal, 2004)

\section{Perencanaan Biaya}

Perencanaan biaya menurut (Supriyono, 2004) memberikan keterangan bahwa proses untuk menentukan tujuan organisasi yang dilaksanakan, maka perencanaan ini dapat disusun jangka pendek atau jangka panjang, dan akan diperguankan sebagai dasar untuk mengendalikan kegiatan perusahaan. Oleh sebab itu jika dibandingkan dengan fungsi perencanaan lainnya maka perencanaan adalah masalah yang sangat vital, sebab perencanaan pada dasarnya merupakan kerangka dasar pelaksanaan semua fungsi lainnya.

Membuat perencanaan yang tepat memang diperlukan langkah-langkah yang tepat pula, dalam hal ini (Suadi, 2004) memberikan rincian langkah dalam perencanaan sebagai berikut :

1. Menetapkan tujuan

2. Menyusun anggapan-anggapan

3. Menentukan berbagai alternative tindakan

4. Mengadakan penilaian terhadap alternatif tindakan yang sudah dipilih

5. Mengambil keputusan

6. Menyusun perencanaan mendatang.

\section{Penyusunan Anggaran}

Menurut Supriyono $(2004,17)$ periode anggaran merupakan faktor penting dalam penyusunan rencana anggaran yang lengkap dan hal ini periode anggaran dapat disusun atas dasar sebagai berikut :

1. Anggaran Jangka Panjang

Merupakan anggaran yang disusun untuk jangka waktu beberapa tahun misalnya 3 atau 5 tahun, mungkin akan terjadi bebrapa tahun yang akan dating tentang jumlah laba yang akan dicapai dan sekaligus menyusun :

a. Anggaran penjualan 
b. Anggaran variabel dan biaya tetap yang meliputi biaya produksi, biaya administrasi dan umum serta pemasaran

c. Anggaran neraca

d. Anggaran ekspansi dan intervensi aktivasi tetap.

\section{Anggaran Tahunan}

Merupakan anggaran yang disusun dalam jangka waktu satu tahun atau satu periode akuntasi.

3. Anggaran Bulanan

Merupakan anggaran yang disusun lebih terperinci untuk setiap bulan dalam tahun anggaran yang bersangkutan dan disusun lebih terperinci dalam jangka waktu lebih pendek.

Anggaran biasanya berjangka waktu satu tahun dan dirinci untuk setiap semester atau setiap triwulan, atau setiap bulan selama tahun yang bersangkutan, adapun langkah-langkah di dalam penyusunan anggaran biasanya sebagai berikut :

1. Menentukan pedoman perecanaan

2. Menyiapkan anggaran penjualan

3. Menyiapkan komponen anggaran lainnya

4. Perundingan untuk menyesuaikan rencana final setiap komponen anggaran

5. Mengkoordinasikan dan menelaah komponen anggaran

6. Mengesahkan anggaran final

7. Pendistribusian anggaran yang telah disahkan (Supriyono, 2005).

\section{METODOLOGI PENELITIAN}

\section{Struktur Pengendalian Intern}

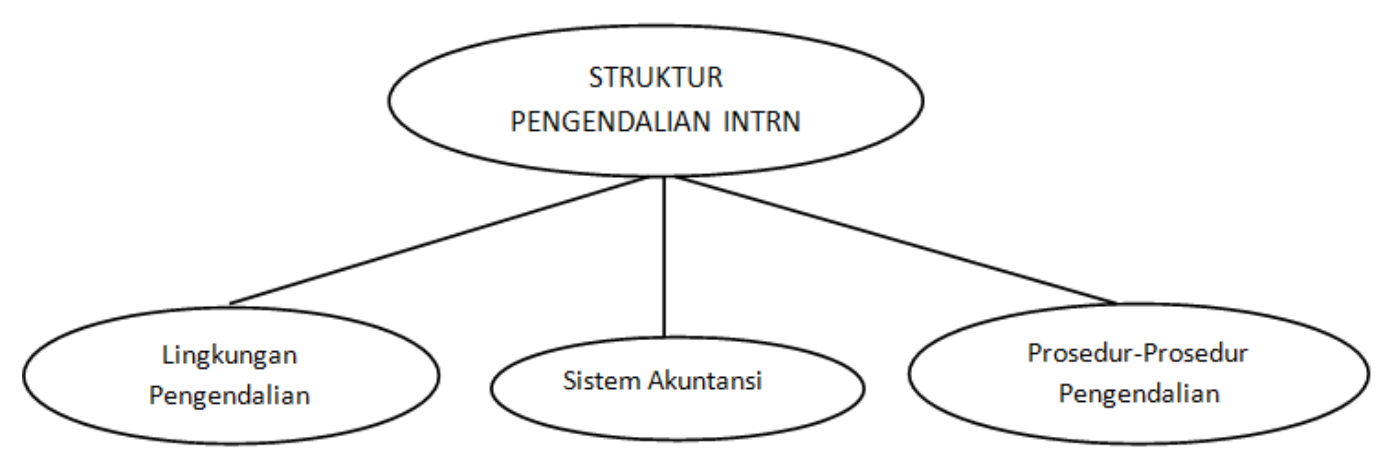


Sumber: Bodnar dan Hopwood,2000

Unsur-Unsur Pengendalian Internal:

1. Lingkungan Pengendalian

2. Sistem Akuntansi

3. Prosedur Pengendalian

Keterangan :

1. Lingkungan Pengendalian

Lingkungan Pengendalian dari suatu organisasi menekankan pada berbagai macam faktor yang secara bersamaan mempengaruhi kebijakan dan prosedur pengendalian.

\subsection{Filosofi dan Gaya Operasional Manajemen}

Filosofi adalah seperangkat keyakinan dasar yang menjadi parameter bagi perusahaan dan karyawannya. (menggambarkan apa yang seharusnya dikerjakan dan yang tidak dikerjakan). Gaya Operasional mencerminkan ide manajer tentang bagaimana kegiatan operasi suatu perusahaan harus dikerjakan. (Filosofi perusahaan dikomunikasikan melalui gaya operasi manajemen)

\subsection{Struktur Organisasi}

Salah satu elemen kunci dalam lingkungan pengendalian adalah struktur organisasi. Struktur Organisasi menunjukkan pola wewenang dan tanggung jawab yang ada dalam suatu perusahaan. (Desentralisasi maupun sentralisasi)

- Dewan Komisaris dan Audit Komite

Dewan komisaris merupakan penghubung antara pemegang saham dengan pihak manajemen perusahaan. Pemegang saham mempercayakan pengendalian atas manajemen melalui dewan komisaris. (jadi semuanya tergantung dari dewan komisaris)

- Komite audit dibentuk oleh dewan komisaris untuk melaksanakan pengawasan terhadap pelaksanaan pengendalian operasional perusahaan. 
Metode Pendelegasian Wewenang dan Tanggung Jawab

Metode pendelegasian wewenang dan tanggung jawab mempunyai pengaruh yang penting dalam lingkungan pengendalian. Biasanya metode ini tercermin dalam suatu bagan organisasi.

1. Metode Pengendalian Manajemen

Lingkungan pengendalian juga dipengaruhi oleh metode pengendalian manajemen.Metode ini meliputi pengawasan yang efektif (melalui peranggaran), laporan pertanggung jawaban dan audit internal.

2. Kebijakandan praktek kepegawaian

Kebijakan dan praktek yang berhubungan dengan perekrutan, pelatihan, evaluasi, penggajian dan promosi pegawai, mempunyai pengaruh yang penting dalam mencapai tujuan perusahaan sebagaimana juga dilakukan dalam meminimumkan resiko.

3. Pengaruh Ekstern

Organisasi harus mematuhi aturan-aturan yang dikeluarkan oleh pemerintah maupun pihak yang mempunyai juridiksi atas organisasi.Hal tersebut sangat berpengaruh pada pengendalian intern perusahaan.

\section{Sistem Akuntansi}

Sistem akuntansi tidak hanya digunakan untuk menghasilkan laporan keuangan saja, tetapi juga menghasilkan pengendalian manajemen.

3. Prosedur pengendalian

Prosedur pengendalian merupakan kebijakan dan aturan mengenai kelakuan karyawan yang dibuat untuk menjamin bahwa tujuan pengendalian manajemen dapat tercapai. Secara umum prosedur pengendalian yang baik terdiri dari :

3.1. Penggunaan wewenang secara tepat untuk melakukan suatu kegiatan atau transaksi.

3.2. Pembagian tugas.

3.3. Pembuatan dan penggunaan dokumen dan catatan yang memadai.

3.4. Keamanan yang memadai terhadap aset dan catatan.

3.5. Pengecekan independen terhadap kinerja. 
Penjelasan tentang porosedur pengendalian di atas, yaitu:

1. Penggunaan wewenang secara tepat

Dalam organisasi, setiap transaksi hanya terjadi atas dasar otorisasi dari pejabat yang memiliki wewenang untuk menyetujui terjadinya transaksi tersebut. Oleh karena itu dalam organisasi harus dibuat sistem yang mengatur pembagian wewenang untuk otorisasi atas terlaksananya setiap transaksi. Dengan adanya pembagian wewenang ini akan mempermudah jika akan dilakukan audit trail, karena otorisasi membatasi aktivitas transaksi hanya pada orang-orang yang terpilih. Otorisasi mencegah terjadinya penyelewengan transaksi kepada orang lain.

2. Pembagian tugas

Pembagian tugas memisahkan fungsi operasi dan penyimpanan dari fungsi akuntansi (pencatatan). Dan suatu fungsi tidak boleh melaksanakan semua tahap suatu transaksi.Dengan pemisahakn fungsi operasi dan penyimpanan dari fungsi pencatatan, catatan akuntansi yang disiapkan dapat mencerminkan transaksi yang sesungguhnya terjadi pada fungsi operasi dan fungsi penyimpanan. Jika semua fungsi disatukan, akan membuka kemungkinan terjadinya pencatatan transaksi yang sebenarnya tidak terjadi, sehingga informasi akuntansi yang dihasilkan tidak dapat dipercaya kebenarannya, dan sebagai akibatnya kekayaan organisasi tidak terjamin keamanannya.

3. Dokumen dan catatan yang memadai.

Prosedur harus mencakup perancangan dan penggunaan dokumen dan catatan yang memadai untuk membantu meyakinkan adanya pencatatan transaksi dan kejadian secara memadai. Selanjutnya dokumen dan catatan yang memadai akan menghasilkan informasi yang teliti dan dapat dipercaya mengenai kekayaan, utang, pendapatan dan biaya suatu organisasi.(biasanya dilakukan berdampingan dengan penggunaan wewenang secara tepat).

4. Keamanan yang memadai Terhadap aset dan catatan.

Keamanan yang memadai meliputi pembatasan akses ke tempat penyimpanan aset dan catatan perusahaan untuk menghindari terjadinya pencurian aset dan data/informasi perusahaan.

5. Pengecekan independen terhadap kinerja

Semua catatan mengenai aktiva yang ada harus dibandingkan (dicek) secara periodik dengan aktiva yang ada secara fisik. Pengecekkan inni harus dilakukan oleh suatu unit organisasi yang independen (selain unit fungsi penyimpanan, unit fungsi operasi dan unit fungsi pencatatan) untuk menjaga objektivitas pemeriksaan. 
Hubungan sistem akuntansi dan pengendalian internal. Pengendalian internal merupakan bagian integral dari sistem informasi akuntansi. Pengendalian internal itu sendiri adalah suatu proses yang dijalankan untuk perusahaan, manajemen dalam usaha yang dikelola. Kriteria dari pengendalian internal keandalan pelaporan keuangan, efektivitas efisiensi operasi dan keputusan terhadap hukum dan peraturan yang berlaku. Menetapkan serta menerapkan pengendalian internal maka wirausahawan mampu mencapai tujuan dan meminimalkan resiko. Sebagai hasil dari ditetapkannnya pengendalaian internal dalam sisten informasi akuntansi adalah dihasilkannya informasi akuntansi yang berkualitas dan dapat di audit.

Sistem informasi akuntansi ini dirancang sedemikian rupa oleh suatu perusahaan sehingga dapat memenuhi fungsinya yaitu menghasilkan informasi akuntansi yang tepat waktu, relevan dan dapat dipercaya. Sistem informasi akuntansi terkandung unsur-unsur pengendalian, maka baik buruknya sistem informasi akuntansi sangat mempengaruhi fungsi manajemen dalam melakukan pengendalian internal, karena informasi yang dihasilkannya akan dijadikan salah satu dasar dalam pengambilan keputusan yang berkaitan dengan aktivitas perusahaan. Mengingat begitu pentingnya penerapan sistem informasi akuntansi dalam suatu perusahaan, maka tidak dapat dibayangkan bagaimana jadinya kalau suatu perusahaan tidak memiliki sistem informasi akuntansi yang memadai. Perusahaan tersebut mungkin tidak dapat memproses transaksinya secara jelas, terinci dan terstruktur. Kemudian perusahaan tersebut mungkin tidak akan memperoleh informasi yang relevan dan dapat dipercaya yang diperlukannya untuk dijadikan dasar dalam mengambil keputusan yang menyangkut aktivitas dan kelangsungan hidup perusahaan.

Selanjutnya karena sistem informasi akuntansi didalamnya mengandung unsur-unsur pengendalian, maka perusahaan mungkin tidak dapat menjalankan pengendalianpengendalian yang diterapkannya dengan baik. Karena pengendalian tidak dijalankan dengan baik, tidak menutup kemungkinan terjadinya penyimpangan-penyimpangan dan kecurangankecurangan yang dilakukan dengan sengaja atau tidak sengaja. Jika penyimpangan dan kecurangan sudah terjadi otomatis aktiva yang dimiliki perusahaan terancam keselamatannya dan aktivitas yang dilakukan menjadi tidak efektif dan efisien 


\section{HASIL DAN PEMBAHASAN}

Pengendalian internal merupakan bagian integral dari sistem informasi akuntansi. Pengendalian internal itu sendiri adalah suatu proses yang dijalankan untuk perusahaan, manajemen dalam usaha yang dikelola. Kriteria dari pengendalian internal keandalan pelaporan keuangan, efektivitas efisiensi operasi dan keputusan terhadap hukum dan peraturan yang berlaku. Menetapkan serta menerapkan pengendalian internal maka wirausahawan mampu mencapai tujuan dan meminimalkan resiko. Sebagai hasil dari ditetapkannnya pengendalaian internal dalam sisten informasi akuntansi adalah dihasilkannya informasi akuntansi yang berkualitas dan dapat di audit.

Berdasarkan data pada tabel 1, perolehan laba yang kurang maksimal karena terjadinya penurunan laba usaha selama tiga tahun terakhir yaitu 2011, 2012 dan 2013.

Langkah realistis yang perlu dilakukan untuk mengatasi masalah pengelolaan usaha pada toko Nabil ada beberapa langkah yang dijalankan Yaitu:

1. Menentukan dan menetapkan anggaran yang cermat dan teliti, sehingga selisih anggaran tidak terlalu besar dan memudahkan dalam proses pengendalian intern untuk biaya operasional, perlu mempertimbangkan adanya perkembangan volume kegiatan usahanya, sehingga anggaran yang ditetapkan berimbang dengan realisasi biaya operasional.

2. Melakukan pengawasan biaya operasional kerena pengelolan dari pihak pengelola usaha masih kurang, karena beberapa biaya operasional meningkat dan pengawasan merupakan cara utama untuk mengatasi terjadinya pemborosan.

3. Konsistensi dalam pengendalian teknis untuk pengeluaran biaya operasional sesuai dengan perencanaan dan aturan otorisasi yang berlaku.

4. Mengadakan pembenahan anggaran, untuk asumsi-asumsi dan patokan anggaran.

Berikut pembagian biaya opersional terkendali dan tidak terkendali yang disarankan:

TABEL 2 :

Biaya Terkendali dan Tidak Terkendali Yang Disarankan

\begin{tabular}{|l|c|c|}
\hline \multicolumn{1}{|c|}{ Biaya Operasional } & Terkendali & Tidak Terkendali \\
\hline Biaya upah karyawan & $\mathrm{T}$ & - \\
\hline Biaya telepon & $\mathrm{T}$ & - \\
\hline Biaya listrik & $\mathrm{T}$ & - \\
\hline Biaya air bersih & $\mathrm{T}$ & - \\
\hline
\end{tabular}




\begin{tabular}{|l|c|c|}
\hline Biaya penyusutan & T & - \\
\hline Biaya kantor & - & TT \\
\hline Biaya pemeliharaan dan perbaikan & - & TT \\
\hline Biaya konsumsi & - & TT \\
\hline Biaya bahan bakar & - & TT \\
\hline
\end{tabular}

Berdasarkan saran pada tabel data biaya yang terkendali dan tidak terkendali, maka dalam menentukan komposisi anggaran atau target pengeluaran biaya operasional yang realistis dengan cara mempertimbangkan aspek potensi dan asumsi anggaran dalam usaha menghindari penyimpangan selisih biaya operasional antara anggaran dan realisasi, sehingga memudahkan untuk pengendalian intern usaha Toko Nabil.

\section{DAFTAR PUSTAKA}

Amin Widjaja Tunggal, 2005.Sistem Pengedalian Manajemen, Rineka Cipta, Jakarta.

Arif Suadi, 2004, Sistem Pengendalian Manajemen, Fakultas Ekonomi, Yogyakarta.

Bodnar H. Goerge dan Hopwood S. William, 2000, Sistem Informasi Akuntansi, Salemba Empat, Jakarta.

Ikatan Akuntan Indonesia, 2010, Standar Akuntan Keuangan, Salemba Empat, Jakarta.

Mulyadi, 2005, Sistem Akuntansi, Edisi 4, STIE YKPN, Yogyakarta.

Supriyono, 2004, Akuntansi Manajemen, Edisi 3, YKPN, Yogyakarta.

Zaki Baridwan, 2009, Sistem Akuntansi, Edisi 6, BPFE, Yogyakarta. 